\title{
ACTIONS OF AMINO-ACIDS ON THE ISOLATED HEMISECTED SPINAL CORD OF THE TOAD
}

BY

\author{
D. R. CURTIS, J. W. PHILliS and J. C. WATKINS
}

From the Department of Physiology, Australian National University, Canberra

(Received February 7, 1961)

\begin{abstract}
The actions of a series of amino-acids related to $\gamma$-aminobutyric acid and glutamic acid have been determined upon the isolated and sagittally hemisected spinal cord of the toad, Bufo marinus. Slow and fast components of the ventral root reflex responses following dorsal root stimulation were depressed by $\gamma$-aminobutyric acid and by a series of neutral amino-acids having a similar structure. The relative depressant potencies of the members of this series were determined by comparison of the concentrations of each required to cause the same reduction in the electrically integrated slow components of these reflex responses. Glutamic acid and closely related substances facilitated reflex responses in low concentrations and depressed these responses in high concentrations. The actions of these substances resulted in the depolarization of motoneurones which was recorded as a negative potential in the ventral root. The relative potencies of the substances were estimated from the concentrations of each required to produce negative potentials of the same magnitude.

Several amino-acids not previously tested proved to have remarkably strong actions on this preparation. 3-Aminopropanesulphonic acid was the most potent depressant tested; homocysteic acid and $\mathrm{N}$-methylaspartic acid were the most powerful excitatory substances. The $D$ forms of optically active depressants or excitants were always stronger than the corresponding $L$ forms where both enantiomorphs were available. Points of similarity and dissimilarity between these results and those of related investigations are discussed.
\end{abstract}

Much interest has centred around the recently revealed ability of certain aminoacids to modify electrical events recorded at neuronal and neuromuscular junctions. These amino-acids can be classified into two broad groups: those which decrease and those which increase the excitability of post-synaptic elements (Curtis \& Watkins, 1960). Substances of the latter group, in concentrations higher than those required to produce excitation, may also cause depression (Brockman \& Burson, 1957 ; Robbins, 1959 ; Van Harreveld, 1959 ; Curtis, Phillis \& Watkins, 1960), but such depression is clearly distinguishable from that manifested at all concentrations by substances of the first group (Curtis, Phillis \& Watkins, 1959 ; Curtis et al., 1960). Amongst the most potent members of these two groups of amino-acids, which can for convenience be termed the depressant and excitant series, are $\gamma$-aminobutyric acid and glutamic acid respectively. These two compounds bear a simple structural relationship to one another, which, for substances applied iontophoretically into the environment of single cells in the cat's spinal cord, is characteristic of members of the two series (Curtis \& Watkins, 1960). Certain differences in the general picture of structure-activity relationships have, however, emerged from studies involving 
various other tissues and test situations (Purpura, Girado, Smith, Callan \& Grundfest, 1959 ; Edwards \& Kuffler, 1959; Van Harreveld, 1959). In particular, several substances which were inactive when applied iontophoretically to single cells in the cat's spinal cord have been reported to have strong actions, either depressant or excitant, on the responses of groups of cells elsewhere in the nervous system when topically applied. It was with the dual purpose of further investigating such differences, and of developing methods for comparing quantitatively the potencies of groups of closely related depressant and excitant substances, that the present work was undertaken. The opportunity was also taken to test, for the first time, several previously unavailable synthetic amino-acids, some of which proved to be remarkably potent on this particular preparation.

\section{METHODS}

All experiments were performed on segments of the isolated spinal cord of the Queensland toad, Bufo marinus. The cord was hemisected sagittally and was fixed in a small trough of $1.5 \mathrm{ml}$. capacity which could be perfused with amphibian Ringer solution of the following composition: $\mathrm{NaCl}, 100 \mathrm{mM} ; \mathrm{KCl}, 2.5 \mathrm{mM} ; \mathrm{Na}_{2} \mathrm{HPO}_{4}, 2.5 \mathrm{mM} ; \mathrm{NaH}_{2} \mathrm{PO}_{4}, 0.45 \mathrm{mM} ; \mathrm{CaCl}_{2}$, $1.9 \mathrm{~mm} ; \mathrm{NaHCO}_{3}, 12 \mathrm{~mm}$; glucose, $2.8 \mathrm{~mm}$. This solution was equilibrated with a mixture of $95 \%$ oxygen and $5 \%$ carbon dioxide before delivery into the trough and its $p \mathrm{H}$ was 7.4. Both cervical and lumbar regions of the spinal cord were used and appropriate dorsal and ventral roots were drawn through small holes in the lateral walls of the trough into pools of liquid paraffin B.P. The trough and paraffin compartments formed portion of the top of a water jacket through which water at $15 \pm 0.5^{\circ} \mathrm{C}$ was circulated. To ensure that the Ringer and test solutions were delivered to the trough at the same temperature, these solutions were passed through coils of polythene tubing immersed in the water jacket. The rate of flow of the Ringer solution between applications of test substances was about $3 \mathrm{ml} . / \mathrm{min}$. No apparent changes took place in the preparation when the circulation of the Ringer solution was interrupted for periods as long as $15 \mathrm{~min}$.

The response of the tissue to an amino-acid was determined from potentials recorded from the ventral roots. Spike potentials and electrotonically propagating slow potentials were recorded monophasically between two non-polarizable electrodes $(\mathrm{Ag}-\mathrm{AgCl})$, one being in the trough of Ringer solution and the other at the crushed end of the ventral root. The effective lengths of the ventral roots were usually about 2 to $4 \mathrm{~mm}$ in cervical preparations and 12 to $14 \mathrm{~mm}$ for a lumbar preparation. Electrical stimuli were applied to dorsal roots by means of a pair of platinum electrodes immersed in the paraffin pool. Two amplifiers were available for recording the subsequent ventral root responses on the oscilloscope, these having time constants of $5 \mathrm{msec}$ and $3 \mathrm{sec}$. The former was suitable for recording the spike components of the reflex, but the latter was necessary to demonstrate the slower components. In many of the experiments the reflex response was also electrically integrated over a period of $600 \mathrm{msec}$ following the stimulus, the integrator having a time constant of $10 \mathrm{sec}$. A directcoupled amplifier was used, in conjunction with either an oscilloscope or a pen-recorder, to record the potentials produced in the ventral root by an amino-acid in the absence of dorsal root stimulation.

The substances to be tested were dissolved in Ringer solution, equilibrated with $95 \%$ oxygen and $5 \%$ carbon dioxide and the $p \mathrm{H}$ readjusted to 7.4 , where necessary, with $\mathrm{N}$ sodium hydroxide or $\mathbf{N}$ hydrochloric acid. The flow of Ringer solution through the trough was interrupted immediately before the application, and the fluid retained by the trough was rapidly flushed out with three to four volumes of the test solution.

The relative potencies of the actions on the isolated toad cord of a series of depressant compounds related to $\gamma$-aminobutyric acid were determined by alternately applying a standard solution of $10^{-3} \mathrm{M} \gamma$-aminobutyric acid and a solution of a particular test substance. The 
concentration of the test substance was varied until the diminution of the integrated ventral root response produced by the $\gamma$-aminobutyric acid and test solutions was the same. Applications of standard and test solutions were each of $1 \mathrm{~min}$ duration, the interval between successive applications being $15 \mathrm{~min}$. Experiments were carried out on at least one lumbar and three cervical preparations for each substance. The relative potencies of the substances were approximately the same on each tissue, irrespective of the particular region which was used.

For comparison of the potencies of excitant compounds, $5 \times 10^{-4} \mathrm{M}$ L-glutamic acid was used as the standard. This solution and solutions of each particular test substance were applied alternately, the concentration of the test substance being varied until the magnitude of the negative potential developed in the ventral root was the same as that produced by the standard glutamic acid solution. Applications were each of $45 \mathrm{sec}$ duration, and the interval between successive applications was again $15 \mathrm{~min}$. To facilitate the comparisons, the potentials developed in the ventral root were monitored by a paper recorder after suitable amplification with a direct-coupled amplifier. As with the depressants, most of the excitant substances were tested both on cervical and lumbar segments, there again being no significant differences in the relative potencies of the substances observed in the two series. No substance, either excitant or depressant, was tested in a concentration greater than $5 \times 10^{-2} \mathrm{M}$; if a substance was without effect at this concentration, it was considered to be inactive.

\section{Interpretation of recorded potentials}

A volley entering the toad spinal cord in one of the dorsal roots produces a complex response in the corresponding and adjacent ventral roots (Eccles, 1946, 1947; Brookhart, Machne \& Fadiga, 1959). The post-synaptic potentials produced in motoneuronal somas by mono- and poly-synaptic pathways (Araki, Otani \& Furukawa, 1953; Machne, Fadiga \& Brookhart, 1959; Araki, 1960) propagate electrotonically along the axons and are detected by a recording electrode situated on a ventral root as a negative potential. This potential may take several hundred milliseconds to reach a maximum and subside, the actual time depending on the strength and frequency of stimulation. Superimposed upon these slow potentials are fast spike potentials conducted along the axons of those motoneurones in which the excitatory post-synaptic potentials attained threshold level. Such composite responses of the ventral root were evoked by stimulating the dorsal root at frequencies of $12 /$ min or less, the strength of the stimulus being selected to produce a slow ventral root potential reaching a maximum value of about 1 to $2 \mathrm{mV}$. A reliable estimate of the magnitude of these slow potentials can be obtained by integration. With the low frequencies of stimulation used the integrated response remained practically constant for several hours.

These slow negative potentials recorded from the ventral root are a measure of the depolarization of all motoneurones whose axons lie in that particular root. The depolarization which follows dorsal root stimulation represents the sum of excitatory post-synaptic potentials produced monosynaptically by impulses in afferent fibres, together with excitatory and inhibitory post-synaptic potentials produced by interneurones which are activated by the dorsal root volley and which synapse with the motoneurones. When chemical substances are applied to this complex tissue in the absence of dorsal root stimulation, they may affect motoneurones, interneurones, or both of these groups of cells simultaneously. The net effect of such substances upon motoneurones, as determined by the potentials recorded from the ventral root, will depend upon which cells are affected, actions upon interneurones only being important if the cells are actually caused to discharge and thus to generate, either directly or after relay, excitatory or inhibitory post-synaptic potentials upon the membrane of the motoneurones with which they synapse. Thus, negative or positive potentials will be recorded from the ventral root depending upon whether motoneurones are directly depolarized or hyperpolarized by a particular substance, and upon whether the substance causes the discharge of excitatory or inhibitory interneurones. These potentials thus provide evidence of neuropharmacological activity, but give no information as to the original site or mechanism of this action. For such information, it would be necessary to carry out more definite experiments, such as those involving iontophoretic application of the substances to single cells. 


\section{RESULTS \\ $\gamma$-Aminobutyric acid}

Action on the ventral root responses following dorsal root stimulation. Fig. 1 illustrates the depressant action of $\gamma$-aminobutyric acid on the reflex responses of the isolated hemisected spinal cord of the toad. The comparatively short latency components of the reflex responses were recorded from the ventral root of the second and third segments after stimulation of the corresponding dorsal root. After the control response of Fig. $1 \mathrm{~A}$, a solution containing $5 \times 10^{-4} \mathrm{M}$-aminobutyric acid was applied, and the responses $B$ and $C$ were recorded 30 and $80 \mathrm{sec}$ later respectively. The bath was then flushed with Ringer solution, and the preparation had fully recovered $150 \mathrm{sec}$ later (D). Higher concentrations of $\gamma$-aminobutyric acid caused greater depression; Fig. 1, E, F, G, H, and I, J, K, L, illustrates respectively the effects of $10^{-3} \mathrm{M}$ and $5 \times 10^{-3} \mathrm{M}$ on the same reflex response. $\mathrm{E}$ and $I$ are control responses. Responses $F$ and $G$ were recorded 30 and $75 \mathrm{sec}$ after the application of $10^{-3} \mathrm{M} \gamma$-aminobutyric acid, the preparation requiring $2 \mathrm{~min}$ for recovery $(H)$. Responses $J$ and $K$ were recorded 10 and $30 \mathrm{sec}$ after application of $5 \times 10^{-3} \mathrm{M} \gamma$-aminobutyric acid, full recovery (L) in this case taking $6 \mathrm{~min}$.

$$
\gamma \text {-Aminobutyric acid perfused }
$$

Bath washed

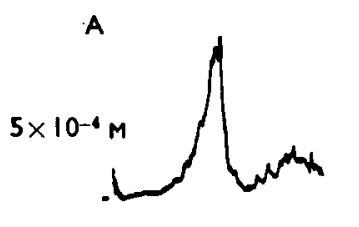

B

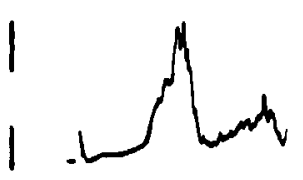

$\int_{-2}^{E-3} M$

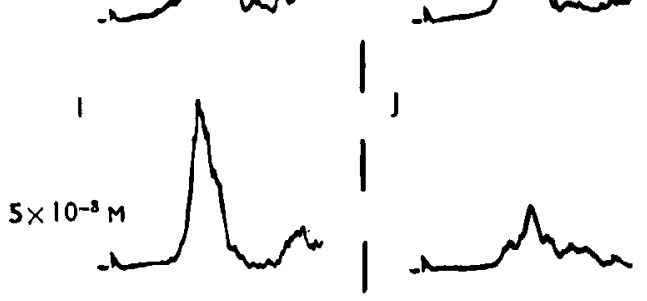

c

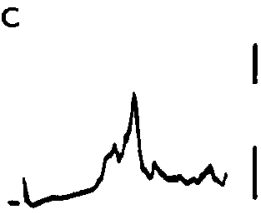

$\mathbf{G}$

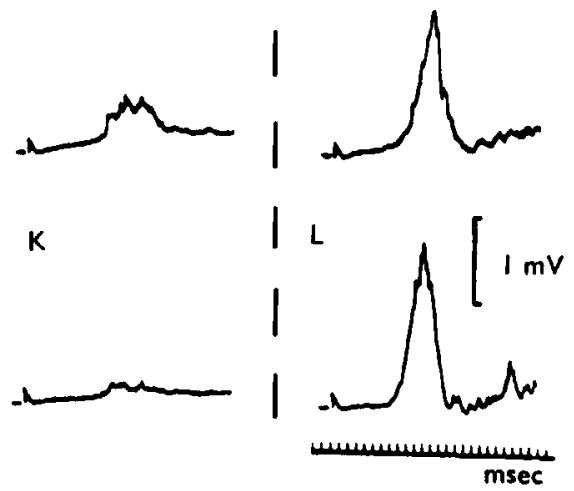

Fig. 1. Reflex discharges recorded from the ventral root of the second and third cervical segments in response to stimulation of the corresponding dorsal root. The intensity of the stimulus remained constant throughout the series. A, E, and J, control responses; $\mathrm{B}$ and $\mathrm{C}$ were recorded 30 and $80 \mathrm{sec}$ after the commencement of perfusion with $5 \times 10^{-4} \mathrm{M} \gamma$-aminobutyric acid; $F$ and $G$, after 30 and $75 \mathrm{sec}$ of perfusion with $10^{-3} \mathrm{M} \gamma$-aminobutyric acid; $J$ and $K$, after 10 and $30 \mathrm{sec}$ of perfusion with $5 \times 10^{-3} \mathrm{M} \gamma$-aminobutyric acid; $\mathrm{D}, \mathrm{H}$, and L, were recorded 150,120, and $360 \mathrm{sec}$ respectively in the corresponding series after washing the bath with amphibian Ringer solution. There was an interval of 15 min between each series. Time marker, msec. Voltage calibration, $1 \mathrm{mV}$. 
The effects of $\gamma$-aminobutyric acid on both the faster and slower components of the ventral root reflex following dorsal root stimulation are shown in Fig. 2. The upper responses were recorded using an amplifier of $3 \mathrm{sec}$ time constant and show the slow potential superimposed upon which are the faster components. Records $\mathrm{A} \mathrm{i}, \mathrm{B} \mathrm{i}$ and $\mathrm{C} \mathrm{i}$ are the responses before, during and after the application of $10^{-3} \mathrm{M}$ $\gamma$-aminobutyric acid, and demonstrate the marked depression of both fast and slow components of the reflex. The lower responses $\mathrm{A}$ ii, $\mathrm{B}$ ii and $\mathrm{C}$ ii are the electrically integrated records of the responses $\mathrm{A} \mathrm{i}, \mathrm{B} \mathrm{i}$ and $\mathrm{C} \mathrm{i}$, and show the depression more clearly.

A

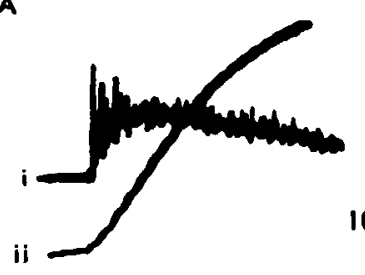

B

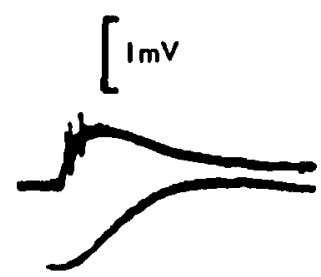

C

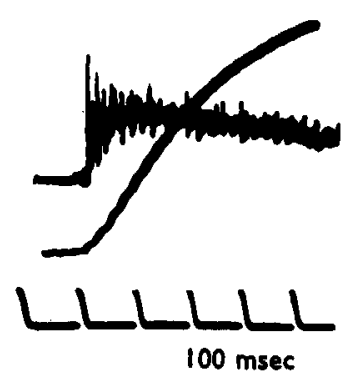

D

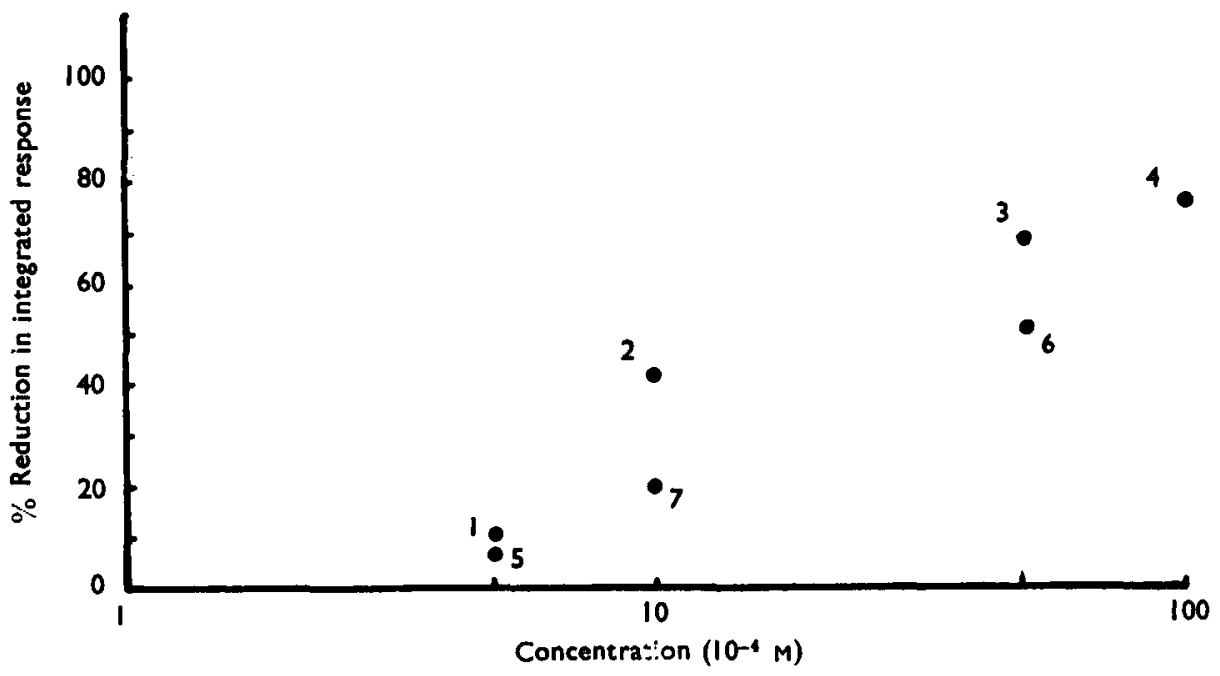

Fig. 2. A to $\mathrm{C}$, Reflex responses evoked by dorsal root stimulation and recorded from the ninth spinal ventral root. i-Using an amplifier of $3 \mathrm{sec}$ time constant. ii-Simultaneous record of the integral, with respect to time, of $i$. A-Control responses; B-after $55 \mathrm{sec}$ perfusion with $10^{-9}$ M $\gamma$-aminobutyric acid; $\mathrm{C}-70 \mathrm{sec}$ after washing the bath. Time-100 msec. Voltage calibration $-1 \mathrm{mV}$ for $i$. $\mathrm{D}$, The depression of the integrated ventral root response produced by a series of concentrations of $\gamma$-aminobutyric acid, same preparation as $A$ to $C$. Ordinate, percentage decrease of the integrated response relative to the control. Abscissa, concentration of $\gamma$-aminobutyric acid in the perfusing solution. All applications were of $50 \mathrm{sec}$ duration and are numbered in the sequence of testing. 
The depression produced by $\gamma$-aminobutyric acid was related to the concentration. It was found, however, that repeated applications of this drug in high concentration frequently resulted in a decline in depressant efficacy. These results are illustrated in Fig. 2 D. The points 1 to 4 represent the percentage reduction of the integrated ventral root response evoked by a dorsal root stimulus with a series of increasing concentrations of $\gamma$-aminobutyric acid. After the applications of this series, the solutions having the concentrations corresponding to points 1,2 and 3 were re-tested, and each was found to give a much diminished depression of the integrated response (points 5, 7 and 6 respectively). In this experiment the applications were made in the sequence represented by the numerals; the time interval between successive applications was $15 \mathrm{~min}$.

Potentials recorded from the ventral root in the absence of dorsal root stimulation. In most preparations, $\gamma$-aminobutyric acid, even in concentrations as high as $10^{-2} \mathrm{M}$, caused no significant potential change in the ventral root in the absence of dorsal root stimulation. In a few experiments, however, the drug elicited a positive potential of varying magnitude (mostly in the range of 0.5 to $1 \mathrm{mV}$ with $10^{-3} \mathrm{M} \gamma$-aminobutyric acid), which indicated that the motoneuronal membranes had in these instances been hyperpolarized from the prevailing resting state. This effect seemed to be seasonal and may reflect changes in extra- and intra-cellular ionic concentrations (Machne et al., 1959). It was also found that repeated applications of $\gamma$-aminobutyric acid to such preparations invariably resulted in a progressive diminution in the positive potential developed, and, often, ultimately to complete disappearance of the effect. Although this variable phenomenon did not influence significantly the observed relative potencies of a series of depressant compounds closely related to $\gamma$-aminobutyric acid, nevertheless, in order to maintain a greater uniformity of test conditions, only those spinal cords in which such a hyperpolarizing response was minimal were selected for comparative experiments.

\section{L-Glutamic acid}

Action on the fast components of the ventral root responses following dorsal root stimulation. Fig. 3 illustrates the effects of three progressively increasing concentrations of L-glutamic acid upon responses recorded from the ventral root of the isolated toad cord. The responses shown are those recorded from the ventral root following dorsal root stimulation ( $A$ to $D, E$ to $H$ and $M$ to $P$ ) and in the absence of dorsal root stimulation (I to $L$ ). After the control response A, a solution containing $5 \times 10^{-4} \mathrm{M}$ glutamic acid was applied and the responses $\mathrm{B}$ and $\mathrm{C}$ recorded 10 and $50 \mathrm{sec}$ later. The glutamic acid solution was then flushed out, the recovered response $\mathrm{D}$ being recorded $2 \mathrm{~min}$ later. The responses of $\mathrm{Fig} .3 \mathrm{E}$ to $\mathrm{H}$ are analogous to those of $A$ to $D$, except that the concentration of L-glutamic acid was $5 \times 10^{-3} \mathrm{M}$. These records show the marked increase in the fast components of the reflex and the depression of the slow component upon which the spikes were superimposed. Fig. 3, I to L, shows spike responses evoked in the ventral root by $5 \times 10^{-3} \mathrm{M} \mathrm{L}$ glutamic acid in the absence of dorsal root stimulation; the responses $\mathrm{J}$ to $\mathrm{L}$ were recorded at the same time intervals after the control (I) as those of $A$ to $D$ and $E$ to $H$. The responses of Fig. 3, $M$ to $P$, demonstrate the typical effect of high 


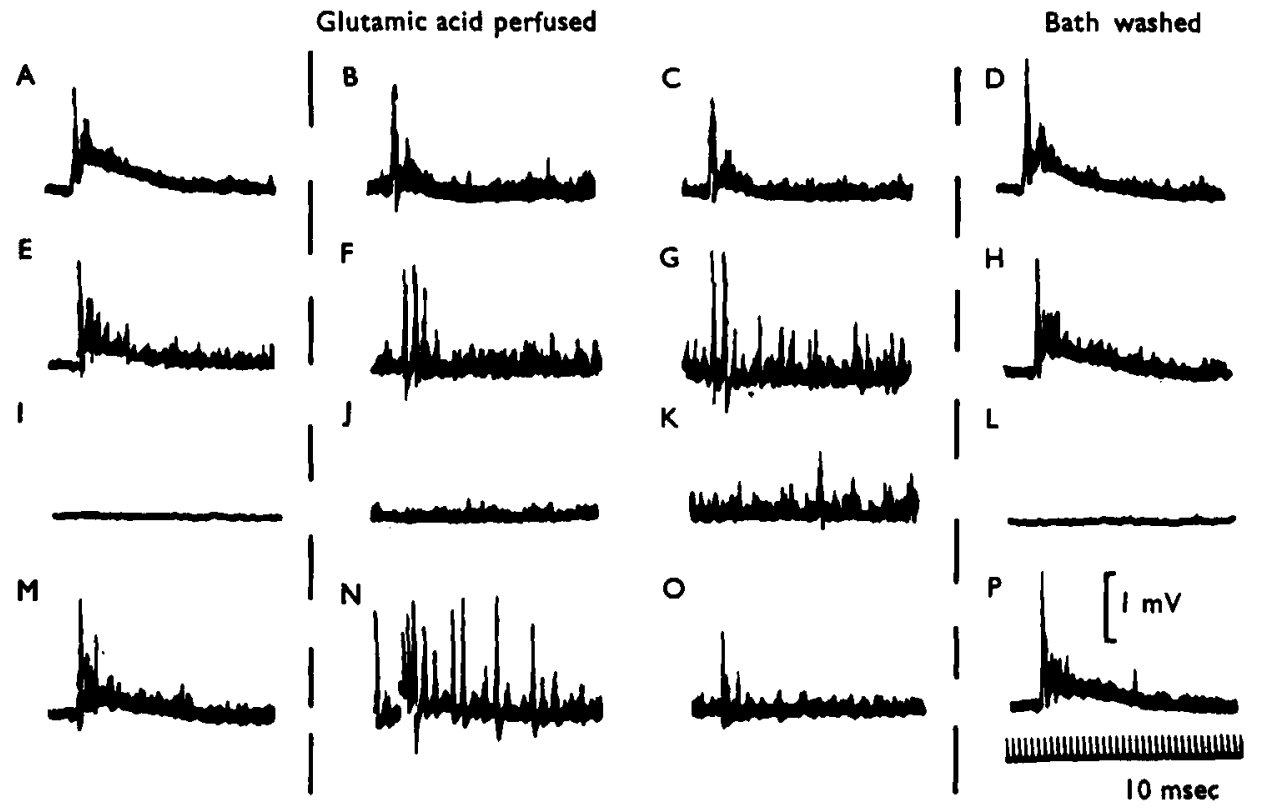

Fig. 3. The action of $L$-glutamic acid upon reflex activity $A$ to $H, M$ to $P$, and upon spontaneous activity recorded from the ventral root, I to $\mathrm{L}$. A, E, I, and M-controls. B, F, and J were recorded $10 \mathrm{sec}$ and $\mathrm{C}, \mathrm{G}$, and $\mathrm{K} 30 \mathrm{sec}$ after the application of solutions containing $5 \times 10^{-4} \mathrm{M}$, $5 \times 10^{-3} \mathrm{M}$, and $5 \times 10^{-3} \mathrm{M} \mathrm{L-glutamic}$ acid respectively. $\mathrm{N}$ and $\mathrm{O}$ were recorded 50 and $56 \mathrm{sec}$ after the application of $10^{-8} \mathrm{M}$ L-glutamic acid solution. $\mathrm{D}, \mathrm{H}, \mathrm{L}$, and $\mathrm{P}, 120 \mathrm{sec}$ after washing bath with Ringer solution. There was an interval of $15 \mathrm{~min}$ between each series. Time, $10 \mathrm{msec}$. Voltage calibration, $1 \mathrm{mV}$.

concentrations of glutamate in causing a progressive increase in the reflex response to a maximum, this being followed by sudden and severe depression during which dorsal root stimulation evoked practically no response from the ventral root: $\mathbf{M}$ is the control response, $\mathrm{N}$ and $\mathrm{O}$ were recorded 50 and $56 \mathrm{sec}$ after application of $10^{-2} \mathrm{M}$ L-glutamic acid; the bath was then flushed with Ringer solution and the response $\mathbf{P}$ was recorded 2 min later.

Action on the slow potential recorded from the ventral root following dorsal root stimulation. Although the number of spike components of the ventral root reflex was greatly increased by L-glutamic acid, the slow potential upon which these spikes were superimposed was markedly decreased. This can be seen both in the responses of Fig. 3 and those of Fig. 4. The latter figure shows, on a compressed time scale, the change in the magnitude of these slow potentials induced by three concentrations of L-glutamic acid. The responses were recorded using a direct-coupled amplifier in conjunction with a pen recorder. The left- and right-hand arrows on each of the records $\mathrm{A}$ to $\mathrm{C}$ demonstrate the points of application and washing out of the solutions respectively. The alteration in the position of the base line in these records is an indication of changes in the prevailing potential across motoneurone membranes, such potentials spreading electrotonically along the ventral roots. Fig. 4 shows the changes in the base line potential induced by $2 \times 10^{-4} \mathrm{M}(\mathrm{A}), 3 \times 10^{-4} \mathrm{M}$ (B) and 
A
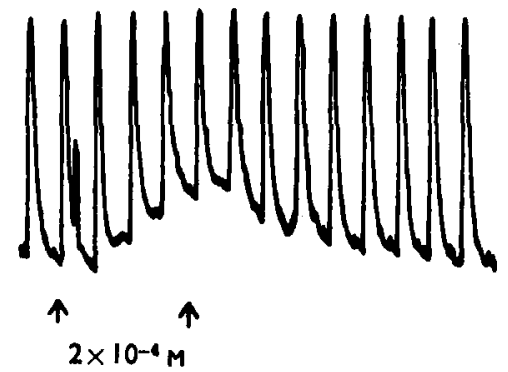

B
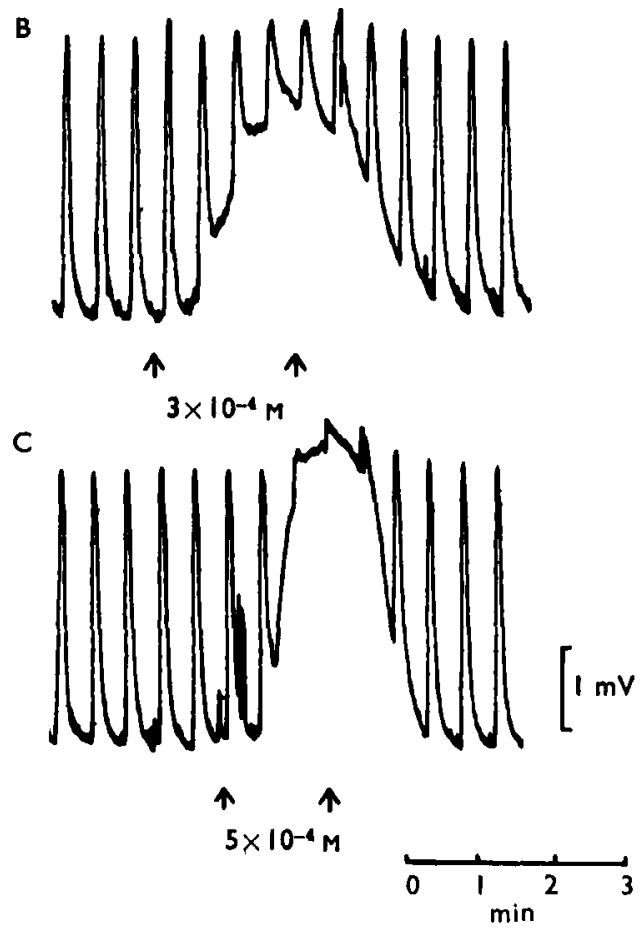

Fig. 4. Potentials recorded from the ventral root of a lumbar preparation using a direct-coupled amplifier and a paper recorder. The dorsal root was stimulated maximally twice per min throughout. At the first arrow in each record L-glutamic acid at concentrations of $2 \times 10^{-4} \mathrm{M}$ (A), $3 \times 10^{-8} \mathrm{M}(\mathrm{B})$, and $5 \times 10^{-4} \mathrm{M}(\mathrm{C})$ was perfused through the bath for 2,2 , and $1.5 \mathrm{~min}$ respectively. The bath was washed out at the second arrow. Time, min. Voltage calibration $-1 \mathrm{mV}$ for all records.

$5 \times 10^{-1}$ M (C) L-glutamic acid, and the concomitant progressive decreases in the magnitude of the slow potential as measured from this base line. The effect, which reflects the extent of the glutamate-induced depolarization of motoneurones, was greater the higher the concentration of the amino-acid. As can be seen from Fig. 2, $\gamma$-aminobutyric acid also caused a marked decrease in the magnitude of the slow potential, but the effect in this instance was not accompanied by any significant change in the base line potential.

Potentials produced in the ventral root by L-glutamic acid in the absence of dorsal root stimulation. The application of relatively dilute solutions (less than $5 \times 10^{-4} \mathrm{M}$ ) 


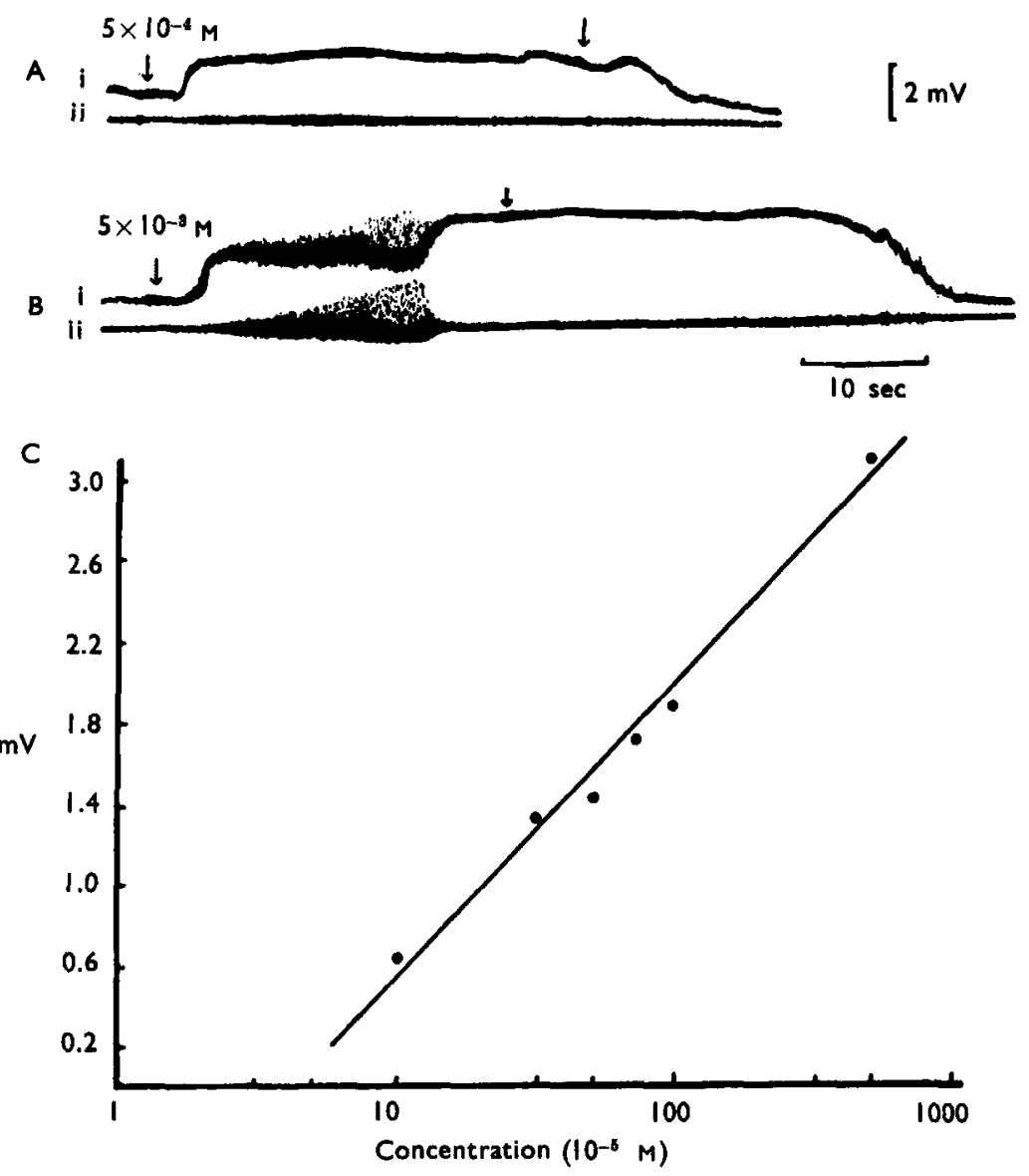

Fig. 5. A, B, Potentials recorded from the ventral root of a cervical preparation in the absence of dorsal root stimulation. Negativity upwards. i-Using a direct-coupled amplifier; iiusing an amplifier having a 5 msec time constant. A- $5 \times 10^{-*} \mathrm{M}$ L-glutamic acid was perfused through the bath (first arrow) for $35 \mathrm{sec}$. The second arrow indicates the time when the bath was washed out. B- $5 \times 10^{-3} \mathrm{M}$ L-glutamic acid applied in a similar fashion for $28 \mathrm{sec}$. Time $10 \mathrm{sec}$. Voltage calibration, $2 \mathrm{mV}$ for $\mathrm{i}$ and ii. C, The magnitude of the potential recorded from the ventral root, in an experiment similar to that of $A$ and $B$, in response to L-glutamic acid. Ordinate, potential in $\mathrm{mV}$. Abscissae, concentration of L-glutamic acid in the perfusing solution. All applications were of $\mathbf{4 5} \mathrm{sec}$ duration.

of L-glutamic acid to the isolated toad spinal cord resulted in a depolarization of motoneurones, this being recorded as a negative potential by the electrode situated on the ventral root. Higher concentrations of glutamic acid caused the development of a greater negative potential and also evoked discharges of motoneurones as indicated by spike responses recorded from the ventral root. Fig. 5 illustrates these effects ; $\mathrm{A}$ i and $\mathrm{B} i$ are the traces obtained of the potentials recorded between the ventral root and the bath with a direct-coupled amplifier, and $\mathbf{A}$ ii and $B$ ii are the records of spike responses recorded from the ventral root with an amplifier of short time constant $(5 \mathrm{msec})$. When $5 \times 10^{-4} \mathrm{M}$ L-glutamic acid (A) was used, relatively few spike discharges were recorded from the ventral root (record $A$ ii); however, 
3 sec after the application of this solution (left-hand arrow in A) a negative potential was recorded from the ventral root ( $\mathrm{A}$ i); this potential rapidly attained a plateau which was thereafter maintained until shortly after the glutamic acid solution was flushed out (right-hand arrow in A). Recovery took 10 to $12 \mathrm{sec}$. The higher concentration of glutamic acid used in B $\left(5 \times 10^{-3} \mathrm{M}\right)$ caused many motoneurones to discharge impulses, as is evident from both records, $\mathrm{B}$ i and B ii. An increasing number of motoneurones became involved until a maximum was reached, at which point spike responses ceased and the depolarization ascended to a new plateau, this being maintained for approximately $25 \mathrm{sec}$ after the glutamate solution was washed out. Renewed spike activity was evident during the later stages of the recovery, which required about $40 \mathrm{sec}$ to reach completion. The cessation of highfrequency spike activity concomitant with the rise in the level of depolarization during the presence of glutamate has a parallel in the sudden decline in reflex responses with high concentrations of glutamate, as seen in Fig. 3, O. The type of response exemplified by the records B $\mathrm{i}$ and B ii of Fig. 5 could be obtained with all preparations, but the required concentration of glutamic acid varied somewhat from preparation to preparation.

The potential changes evoked by a series of increasing concentrations of L-glutamic acid are shown for a cervical preparation in Fig. 5, C, in which the logarithm of the concentration of the amino-acid is plotted against the negative potential observed. The relationship was approximately linear over the range of concentrations used. Similar results were obtained from lumbar preparations. Unlike the depressant action of $\gamma$-aminobutyric acid, the excitatory efficacy of L-glutamic acid showed no decline after repeated application in high concentrations.

\section{Comparison of the potencies of depressant and excitant substances}

Two methods were employed for obtaining a quantitative measure of the actions of substances on the isolated toad cord: for depressant substances, the extent of the reduction of the integrated ventral root response following dorsal root stimulation; and, for excitant substances, the magnitude of the negative potentials recorded from the ventral root in the absence of dorsal root stimulation. The latter could also be used qualitatively to differentiate substances whose actions resulted in a depolarization of motoneurones from those substances which did not have this excitant action. This was not so, however, for the integrated ventral root response technique, since excitants, as well as depressants, caused a reduction in the magnitude of these responses. The integrator was used only to summate potentials produced in the ventral root following a dorsal root stimulus, and did not take into account the very slow potentials induced in the ventral root by drug action. As can be seen from the records of Fig. 5, A and B, L-glutamic acid caused a potential to be recorded from the ventral root independently of dorsal root stimulation, and when stimuli were applied to the dorsal root (Fig. 4) the ventral root responses superimposed upon the glutamate-induced potential were smaller than those recorded in the absence of glutamic acid. An integrated record of these responses would have shown a marked reduction in comparison with the control responses recorded in the absence of glutamic acid. Thus, the mere reduction of the integrated record 
of the ventral root response following dorsal root stimulation cannot of itself be taken to indicate depressant activity. Therefore, if this technique is to be used for comparing the potencies of purely depressant compounds, it is necessary that such a depressant action be definitely established for each substance by prior tests. All the substances to be compared were therefore first investigated for their effect on the fast components of the reflex response, excitatory and depressant actions being clearly distinguishable by this test (as shown in Figs. 3 and 1).

Depressant substances related to $\gamma$-aminobutyric acid. The substances of Table 1 bear varying degrees of structural similarity to $\gamma$-aminobutyric acid, all being neutral amino-acids or closely related thereto. Those substances which did not enhance the fast components of the reflex following dorsal root stimulation were tested for depressant potency relative to $\gamma$-aminobutyric acid. An indication of the relative potency of one compound to another was obtained by comparing the concentration of each required to produce the same diminution of the integrated ventral root response. The substances tested were so selected that they formed a series which both paralleled and supplemented similar series previously investigated under other test conditions (Purpura et al., 1959 ; Edwards \& Kuffler, 1959 ; Robbins, 1959 : Van Harreveld, 1959 ; Curtis \& Watkins, 1960). The results are given in Table 1, where the potencies are expressed relative to that of $\gamma$-aminobutyric acid.

The substances fall into three main categories, aminocarboxylic acids, aminosulphonic acids, and guanidinocarboxylic acids, the other substances being simply derived from members of these groups. Although belonging chemically more to the $\gamma$-aminobutyric acid series than to the glutamic acid series, the substances were not all depressant, several indeed exhibiting weak excitatory action. Discussion of these substances is deferred until after that of the excitatory amino-acids related to glutamic acid. Within the three groups A, C and D of Table 1, a similar, but not identical, pattern of activity with respect to chain length was observed. Thus, amongst the $\omega$-aminoalkanecarboxylic acids (Table 1, A), peak depressant activity was associated with a chain length of two carbon atoms between the amino-group and the carboxyl group ( $\beta$-alanine), whilst in the series of $\omega$-aminoalkanesulphonic acids (Table 1, C), in the most active substance (3-aminopropanesulphonic acid), the functional groups are separated by a three-carbon-atom chain. This compound was the most potent depressant tested. In the w-guanidinoalkanecarboxylic acids (Table 1, D) maximum activity occurred where only one carbon atom separated the guanidino-group and the carboxyl group (glycocyamine), but it is probably significant that again three atoms (in this case, $-\mathrm{C}-\mathrm{N}-\mathrm{C}-$ ) separate the acidic group from the terminal amino-group, as was also pointed out by Purpura et al. (1959) and Edwards \& Kuffler (1959). A particularly noticeable feature of the w-aminoalkanesulphonic acid group (Table $1, C$ ) was the very sharply defined optimum chain length for depressant activity, this activity falling off steeply if the chain length was less than two carbon atoms and being transformed into a weakly excitatory action if the chain length exceeded three carbon atoms. A similar transformation of depressant into excitatory action was also observed in the $\omega$-aminoand $\omega$-guanidinoalkanecarboxylic acids, although in these cases the change-over was less abrupt. 
TABLE 1

STRUCTURE-ACTIVITY RELATIONSHIPS OF $\gamma$-AMINOBUTYRIC ACID SERIES

Column 1: The ratio of the concentration of $\gamma$-aminobutyric acid $\left(10^{-3} \mathrm{M}\right)$ to that of the test substance which causes the same degree of depression of the ventral root potentials evoked by dorsal root stimulation. Column 2: Approximate relative activities. (a) Depressant compounds, $\gamma$-aminobutyric acid $=1 \cdot 0$. $<0 \cdot 1,-; 0 \cdot 1$ to $0.3,--; 0.3$ to $1 \cdot 0$, - ; 1.0 to $3 \cdot 0, \ldots+\ldots ; 3.0$ to $10, \ldots-\ldots+$ (b) Excitant compounds, based on the method used in Table 2, see columns 1 and 2 of Table 2

Structural feature of interest

A. Distance between carboxyl group and amino-group

B. N-Alkylation

C. Replacement of the carboxyl group by the sulphonic acid group

D. Replacement of the amino-group by the guanidinogroup

E. Miscellaneous

$$
\text { Compound }
$$

Glycine

$\beta$-Alanine

$\gamma$-Aminobutyric acid

$\delta$-Aminovaleric acid

6-Aminohexanoic acid

7-Aminoheptanoic acid

8-Amino-octanoic acid

9-Aminononanoic acid

$N$-Methyl- $\beta$-alanine

$N N$-Dimethyl- $\beta$-alanine

$\beta$-Propiobetaine hydrochloric

$\gamma$-Amino- $N$-methylbutyric acid

$\gamma$-Amino- $N N$-dimethylbutyric acid

$\gamma$-Butyrobetaine

Aminomethanesulphonic acid

Taurine

3-Aminopropanesulphonic acid

4-Aminobutanesulphonic acid

$N$-Methyltaurine

Glycocyamine

$\beta$-Guanidinopropionic acid

$\gamma$-Guanidinobutyric acid

8-Guanidinovaleric acid

Creatine

D-a-Alanine

L-a-Alanine

D-Serine

L-Serine

DL-a-Aminoisobutyric acid

DL-Norvaline

L-Valine

DL-Norleucine

L-Leucine

DL-Isoleucine

Isethionic acid

Ethanolamine

$\beta$-Alaninamide

$\gamma$-Aminobutyramide

Creatinine

\begin{abstract}
Structure
$\mathrm{H}_{2} \mathrm{~N} \cdot \mathrm{CH}_{2} \cdot \mathrm{CO}_{2} \mathrm{H}$

$\mathrm{H}_{2} \mathrm{~N}$. $\left[\mathrm{CH}_{2}\right]_{2} \cdot \mathrm{CO}_{2} \mathrm{H}$

$\mathrm{H}_{2} \mathrm{~N}$. $\left[\mathrm{CH}_{2}\right]_{9} \cdot \mathrm{CO}_{2} \mathrm{H}$

$\mathrm{H}_{2} \mathrm{~N}$. $\left[\mathrm{CH}_{2}\right]_{4}, \mathrm{CO}_{2} \mathrm{H}$

$\mathrm{H}_{2} \mathrm{~N}$. $\left[\mathrm{CH}_{2}\right]_{5} . \mathrm{CO}_{2} \mathrm{H}$

$\mathrm{H}_{2} \mathrm{~N}$. $\left[\mathrm{CH}_{2}\right]_{6} \cdot \mathrm{CO}_{2} \mathrm{H}$

$\mathrm{H}_{2} \mathrm{~N}$. $\left[\mathrm{CH}_{2}\right]_{7} \cdot \mathrm{CO}_{2} \mathrm{H}$

$\mathrm{H}_{2} \mathrm{~N}$. $\left[\mathrm{CH}_{2}\right]_{8} \cdot \mathrm{CO}_{2} \mathrm{H}$
\end{abstract}

$\mathrm{CH}_{3} \cdot \mathrm{NH} \cdot\left[\mathrm{CH}_{2}\right]_{2} \cdot \mathrm{CO}_{2} \mathrm{H}$

$\left(\mathrm{CH}_{3}\right)_{2} \mathrm{~N}$. $\left[\mathrm{CH}_{2}\right]_{2} \cdot \mathrm{CO}_{2} \mathrm{H}$

$\left(\mathrm{CH}_{3}\right)_{3} \mathrm{~N}^{+}\left[\mathrm{CH}_{2}\right]_{2} \cdot \mathrm{CO}_{2} \mathrm{H}\left(\mathrm{Cl}^{-}\right)$

$\mathrm{CH}_{3} \cdot \mathrm{NH} .\left[\mathrm{CH}_{2}\right]_{3} \cdot \mathrm{CO}_{2} \mathrm{H}$

$\left(\mathrm{CH}_{3}\right)_{2} \cdot \mathrm{N} \cdot\left(\mathrm{CH}_{2}\right)_{3} \cdot \mathrm{CO}_{2} \mathrm{H}$

$\left(\mathrm{CH}_{3}\right)_{3} \mathrm{~N}^{+} \cdot\left[\mathrm{CH}_{2}\right]_{3} \cdot \mathrm{CO}_{2}{ }^{-}$

$\mathrm{H}_{2} \mathrm{~N} \cdot \mathrm{CH}_{2} \cdot \mathrm{SO}_{3} \mathrm{H}$

$\mathrm{H}_{2}$ N. $\left[\mathrm{CH}_{2}\right]_{2} \cdot \mathrm{SO}_{3} \mathrm{H}$

$\mathrm{H}_{2} \mathrm{~N}$. $\left[\mathrm{CH}_{2}\right]_{3} . \mathrm{SO}_{3} \mathrm{H}$

$\mathrm{H}_{2} \mathrm{~N} .\left[\mathrm{CH}_{2}\right]_{4} \cdot \mathrm{SO}_{3} \mathrm{H}$

$\mathrm{CH}_{3} \cdot \mathrm{NH} \cdot\left[\mathrm{CH}_{2}\right]_{2} \cdot \mathrm{SO}_{3} \mathrm{H}$

$\mathrm{H}_{2} \mathrm{~N} . \mathrm{C}(\mathrm{NH}) . \mathrm{NH} . \mathrm{CH}_{2} . \mathrm{CO}_{2} \mathrm{H}$

$\mathrm{H}_{2}$ N.C(: $\left.\mathrm{NH}\right)$. NH. $\left[\mathrm{CH}_{2}\right]_{2} \cdot \mathrm{CO}_{2} \mathrm{H}$

$\mathrm{H}_{2} \mathrm{~N}$.C ( : NH).NH. $\left[\mathrm{CH}_{2}\right]_{2} \cdot \mathrm{CO}_{2} \mathrm{H}$

$\mathrm{H}_{2}$ N.C (:NH).NH. $\left[\mathrm{CH}_{2}\right]_{1}, \mathrm{CO}_{8} \mathrm{H}$

$\mathrm{H}_{2} \mathrm{~N}$.C $(: \mathrm{NH}) \cdot \mathrm{N}\left(\mathrm{CH}_{3}\right) \cdot \mathrm{CH}_{2} \cdot \mathrm{CO}_{2} \mathrm{H}$

$\mathrm{CH}_{3} \cdot \mathrm{CH}\left(\mathrm{NH}_{2}\right) \cdot \mathrm{CO}_{2} \mathrm{H}$

HO. $\mathrm{CH}_{2} \cdot \mathrm{CH}\left(\mathrm{NH}_{2}\right) \cdot \mathrm{CO}_{2} \mathrm{H}$

$\mathrm{CH}_{3} \cdot \mathrm{C}\left(\mathrm{NH}_{2}\right)\left(\mathrm{CH}_{3}\right) \cdot \mathrm{CO}_{2} \mathrm{H}$

$\mathrm{CH}_{3} \cdot\left[\mathrm{CH}_{2}\right]_{2} \cdot \mathrm{CH}\left(\mathrm{NH}_{2}\right) \cdot \mathrm{CO}_{2} \mathrm{H}$

$\mathrm{CH}_{3} \cdot \mathrm{CH}\left(\mathrm{CH}_{3}\right) \cdot \mathrm{CH}\left(\mathrm{NH}_{2}\right) \cdot \mathrm{CO}_{2} \mathrm{H}$

$\mathrm{CH}_{3} \cdot\left[\mathrm{CH}_{2}\right]_{3} \cdot \mathrm{CH}\left(\mathrm{NH}_{2}\right) \cdot \mathrm{CO}_{2} \mathrm{H}$

$\mathrm{CH}_{3} \cdot \mathrm{CH}\left(\mathrm{CH}_{3}\right) \cdot \mathrm{CH}_{2} \cdot \mathrm{CH}\left(\mathrm{NH}_{2}\right) \cdot \mathrm{CO}_{2} \mathrm{H}$

$\mathrm{CH}_{3} \cdot \mathrm{CH}_{2} \cdot \mathrm{CH}\left(\mathrm{CH}_{3}\right) \cdot \mathrm{CH}\left(\mathrm{NH}_{2}\right) \cdot \mathrm{CO}_{2} \mathrm{H}$

$\mathrm{HO} .\left[\mathrm{CH}_{2}\right]_{2} . \mathrm{SO}_{3} \mathrm{H}$

$\mathrm{H}_{2} \mathrm{~N} . \mathrm{CH}_{2} \cdot \mathrm{CH}_{2} . \mathrm{OH}$

$\mathrm{H}_{2}$ N. $\left[\mathrm{CH}_{2}\right]_{2}$. $\mathrm{CONH}_{2}$

$\mathrm{H}_{2} \mathrm{~N}$. $\left[\mathrm{CH}_{2}\right]_{3}$. $\mathrm{CONH}_{2}$<smiles>CN1CC(=O)NC1=N</smiles>

2

0.67

$1.4 \quad---$

$0.22 \quad-\frac{1}{0}$

(+)

$(+)$
+

$0 \cdot 25$

$0 \cdot 14$

$0 \cdot 14$

$-\frac{-}{0}$

0.05

$--$

$-$

0

0.02 . -

$1 \cdot 0 \quad--$

3.3 $--\cdots-$

$+$

0

$1 \cdot 0 \quad-\ldots-$

$0 \cdot 17 \quad-\frac{}{0}$

$(+)$

$0 \cdot 25$

$0 \cdot 18$

$-$

$\bar{t}+$

(t)

0
$(+)$

(t)

(t)

(t)

(+)

0

0

$+$ 
TABLE 2

STRUCTURE-ACTIVITY RELATIONSHIPS OF L-GLUTAMIC ACID SERIES

Column 1: The ratio of the concentration of L-glutamic acid $\left(5 \times 10^{-4} \mathrm{M}\right)$ to that of the test substance which causes the same negative potential change in the ventral root. Column 2: Approximate relative activities, $L-g l u t a m i c$ acid $=$ 1.0. $<0.05,(+) ; 0.05$ to $0.15,+; 0.15$ to $0.5,++; 0.5$ to $1.5,+++; 1.5$ to $5,++++; 5$ to $15,+++++$; 15 to $50,++++++;>50,+++++++$. *Mixture of diasterioisomers.

Structural feature of interest

A. Distance between the amino-group and the most distant (w) carboxyl group

B. Optical configuration (see also F, H and $\mathrm{J}$ )

C. Variation of the $\omega$-acidic group

D. Relative disposition of the amino-group and the carboxyl group

E. Substitution in the carbon chain

F. N-Alkylation

G. Replacement of the amino-group by the formamidino group

H. $\omega$-Amide linkages

1. a-Amide linkages

J. Replacement of the amino-group by the hydroxyl group
Compound

Aminomalonic acid

DL-Aspartic acid

DL-Glutamic acid

DL-a-Aminoadipic acid

DL-a-Aminopimelic acid

DL- $a$-Aminosebacic acid

D-Aspartic acid

L-Aspartic acid

D-Glutamic acid

L-Glutamic acid

L-Cysteic acid

DL-Homocysteic acid

L-a-Amino- $\beta$-sulphinopropionic acid

$\beta$-Aminoglutaric acid

2-Aminoethylmalonic acid

DL-2-(Aminomethyl)succinic acid

$\beta$-Hydroxy-DLglutamic acid*

a-Methyl-DLglutamic acid

DL-a€-Diaminopimelic acid $N$-Methyl-DL-aspartic

$N$-Methyl-D-aspartic acid

$N$-Methyl-L-aspartic acid

$N N$-Dimethyl-DLaspartic acid

$N$-Methyl-DL-glutamic acid

$N N$-Dimethyl-L-glutamic acid

a-Glutarobetaine

$N$-Iminomethyl-Laspartic acid

D-Asparagine

L-Asparagine

$N$-Methyl-DL-asparagine

$\beta$-Sulphamoyl-L-alanine L-Glutamine

DL-Isoasparagine

L-Isoglutamine

Tartronic acid

D-Malic acid

L-Malic acid
Structure

$\mathrm{HO}_{2} \mathrm{C}$. $\mathrm{CH}\left(\mathrm{NH}_{2}\right) \cdot \mathrm{CO}_{2} \mathrm{H}$

$\mathrm{HO}_{2} \mathrm{C} . \mathrm{CH}_{3} . \mathrm{CH}\left(\mathrm{NH}_{2}\right) . \mathrm{CO}_{2} \mathrm{H}$

$\mathrm{HO}_{2} \mathrm{C}$. $\left[\mathrm{CH}_{2}\right]_{2} \cdot \mathrm{CH}\left(\mathrm{NH}_{2}\right) \cdot \mathrm{CO}_{2} \mathrm{H}$

$\mathrm{HO}, \mathrm{C} .\left[\mathrm{CH}_{2}\right]_{3} . \mathrm{CH}\left(\mathrm{NH}_{2}\right) . \mathrm{CO}_{2} \mathrm{H}$

$\mathrm{HO}_{2} \mathrm{C} \cdot\left[\mathrm{CH}_{2}\right]_{1} \cdot \mathrm{CH}\left(\mathrm{NH}_{2}\right) \cdot \mathrm{CO} \mathrm{H}$

$\mathrm{HO}_{2} \mathrm{C} \cdot\left[\mathrm{CH}_{2}\right]_{7}, \mathrm{CH}\left(\mathrm{NH}_{2}\right) \cdot \mathrm{CO}_{2} \mathrm{H}$

See A.

$\mathrm{HO}_{8} \mathrm{~S} \mathrm{CH}_{2} \cdot \mathrm{CH}\left(\mathrm{NH}_{2}\right) . \mathrm{CO}_{2} \mathrm{H}$

$\mathrm{HO}_{3} \mathrm{~S} \cdot\left[\mathrm{CH}_{2}\right]_{2} \cdot \mathrm{CH}\left(\mathrm{NH}_{2}\right) \cdot \mathrm{CO}_{2} \mathrm{H}$

$\mathrm{HO}_{2} \mathrm{~S} . \mathrm{CH}_{2}, \mathrm{CH}\left(\mathrm{NH}_{2}\right) \cdot \mathrm{CO}_{2} \mathrm{H}$

$\mathrm{HO}, \mathrm{ClCH}_{9} \mathrm{CH}\left(\mathrm{NH}_{2}\right) . \mathrm{CH}_{2}, \mathrm{CO}_{2} \mathrm{H}$

$\mathrm{HO}_{2} \mathrm{C} . \mathrm{CH}\left(\mathrm{CH}_{2} \cdot \mathrm{CH}_{2} \cdot \mathrm{NH}_{2}\right) \cdot \mathrm{CO}_{2} \mathrm{H}$

$\mathrm{HO}_{2} \mathrm{C} \cdot \mathrm{CH}_{2} \cdot \mathrm{CH}\left(\mathrm{CH}_{2} \cdot \mathrm{NH}_{2}\right) \cdot \mathrm{CO}_{2} \mathrm{H}$

$\mathrm{HO}_{2} \mathrm{C} . \mathrm{CH}_{2} \cdot \mathrm{CH}(\mathrm{OH}) \cdot \mathrm{CH}\left(\mathrm{NH}_{2}\right) \cdot \mathrm{CO}_{2} \mathrm{H}$

$\mathrm{HO}_{2} \mathrm{C} \cdot\left[\mathrm{CH}_{2}\right]_{2} \cdot \mathrm{C}\left(\mathrm{CH}_{3}\right)\left(\mathrm{NH}_{2}\right) \cdot \mathrm{CO}_{2} \mathrm{H}$

$\mathrm{HO}_{2} \mathrm{C} \cdot \mathrm{CH}\left(\mathrm{NH}_{8}\right) \cdot\left[\mathrm{CH}_{2}\right]_{3} \cdot \mathrm{CH}\left(\mathrm{NH}_{2}\right) \cdot \mathrm{CO}_{2} \mathrm{H}$

$\mathrm{HO}_{2} \mathrm{C} \cdot \mathrm{CH}_{2} \cdot \mathrm{CH}\left(\mathrm{NH} \cdot \mathrm{CH}_{3}\right) \cdot \mathrm{CO}_{2} \mathrm{H}$

$\mathrm{HO}_{2} \mathrm{C} \cdot \mathrm{CH}_{8} \cdot \mathrm{CH}\left\{\mathrm{N}\left(\mathrm{CH}_{8}\right)_{2}\right\} \cdot \mathrm{CO}_{2} \mathrm{H}$

$\mathrm{HO}_{2} \mathrm{C} .\left[\mathrm{CH}_{2}\right]_{2} \cdot \mathrm{CH}\left(\mathrm{NH} \cdot \mathrm{CH}_{3}\right) \cdot \mathrm{CO}_{2} \mathrm{H}$

$\mathrm{HO}_{2} \mathrm{C} .\left[\mathrm{CH}_{2}\right]_{2} \cdot \mathrm{CH}\left\{\mathrm{N}\left(\mathrm{CH}_{3}\right)_{2}\right\} \cdot \mathrm{CO}_{2} \mathrm{H}$

$\mathrm{HO}_{2} \mathrm{C} .\left[\mathrm{CH}_{2}\right]_{2} \cdot \mathrm{CH}\left\{\mathrm{N}+\left(\mathrm{CH}_{3}\right)_{3}\right\} \cdot \mathrm{CO}_{2}-$

$\mathrm{HO}_{2} \mathrm{C} \cdot \mathrm{CH}_{2} \cdot \mathrm{CH}(\mathrm{NHCH}=\mathrm{NH}) \cdot \mathrm{CO}_{2} \mathrm{H}$

$\mathrm{HO}_{2} \mathrm{C} . \mathrm{CH}\left(\mathrm{NH}_{2}\right) \cdot \mathrm{CH}_{2} \cdot \mathrm{CONH}_{2}$

$\mathrm{HO}_{2} \mathrm{C} . \mathrm{CH}\left(\mathrm{NH} . \mathrm{CH}_{3}\right) \cdot \mathrm{CH}_{2} \cdot \mathrm{CONH}_{2}$

$\mathrm{HO}_{2} \mathrm{C} . \mathrm{CH}\left(\mathrm{NH}_{2}\right) \cdot \mathrm{CH}_{2} \cdot \mathrm{SO}_{2} \mathrm{NH}_{2}$

$\mathrm{HO}_{2} \mathrm{C} . \mathrm{CH}\left(\mathrm{NH}_{2}\right) \cdot\left[\mathrm{CH}_{2}\right]_{2} \cdot \mathrm{CONH}_{2}$

$\mathrm{HO}_{2} \mathrm{C} . \mathrm{CH}_{2} \cdot \mathrm{CH}\left(\mathrm{NH}_{8}\right)$. CONH

$\mathrm{HO}_{2} \mathrm{C} \cdot\left[\mathrm{CH}_{2}\right]_{2} \cdot \mathrm{CH}\left(\mathrm{NH}_{2}\right) \cdot \mathrm{CONH}_{2}$

$\mathrm{HO}_{2} \mathrm{C} . \mathrm{CH}(\mathrm{OH}) . \mathrm{CO}_{2} \mathrm{H}$

$\mathrm{HO}_{2} \mathrm{C} . \mathrm{CH}_{2} \cdot \mathrm{CH}(\mathrm{OH}) \cdot \mathrm{CO}_{2} \mathrm{H}$

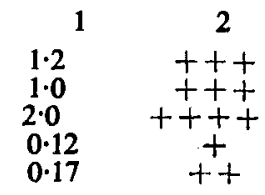

0

$\begin{array}{cc}1.2 & +++ \\ 0.8 & +++ \\ 7.5-2.5 & ++++ \\ & +++ \\ 0.6 & +++ \\ 25 & +++++t \\ 0.8 & +++ \\ 0.42 & ++ \\ & 0 \\ 2.0 & ++++ \\ 1.2 & +++ \\ 0.05 & + \\ & 0\end{array}$

25

$+++++$

70

$5 \cdot 0$

0.5

$3 \cdot 8$

$++t+t+$
$++t+t$

$++t$

0.25

$++t$

$+-r$

0

0.63

$+t$

$1 \cdot 2$

0.33

$0 \cdot 1$

$0 \cdot 071$

0.025

$$
\begin{gathered}
++ \\
+t \\
+ \\
+ \\
+
\end{gathered}
$$

0.05

0.5

0.05 o

$+\frac{t}{t}+$ 
$N$-Alkylation (Table 1, B) caused a graded reduction of depressant activity as the extent of the alkylation increased. This was true both for $\beta$-alanine and for $\gamma$-aminobutyric acid series, in which the trimethyl derivatives were inactive, the dimethyl compounds were slightly active, and the monomethyl derivatives, although more active, were still but weak depressants compared with the unmethylated parent compounds. A single $N$-methyl substituent completely abolished the depressant activity of taurine (compare, for example, taurine and $N$-methyltaurine).

Amongst the series of compounds having miscellaneous structural relationships with $\gamma$-aminobutyric acid (Table 1, E) are several $\alpha$-amino-acids which were tested primarily because of the strong depressant activity of glycine. Of these, $\alpha$-alanine was the only one to show depressant activity, the $\mathrm{D}$ form of this compound being slightly stronger than the $\mathrm{L}$ form. Other $\alpha$-amino-acids, and also creatinine, were found to have excitatory actions, all of which, however, were extremely weak except that of D-serine, which was a moderately strong excitant. The other compounds in this section were inactive.

Excitatory substances related to glutamic acid. The substances of Table 2 bear varying degrees of structural similarity to L-glutamic acid, all being acidic aminoacids or closely related thereto. Their excitant potencies relative to L-glutamic acid were estimated on the basis of the concentrations of each required to produce the same negative potential in the ventral root. The structure-activity relationships apparent from the results listed in Table 2 show, with some exceptions, a very close correlation with those observed amongst the depressant compounds of Table 1 . Thus, in the aminodicarboxylic acid group (Table 2, A), optimum chain length separating the amino-group and w-carboxyl group proved to be three carbon atoms ; in the depressant series (Table 1, A) the optimum chain length separating the analogous groups was two carbon atoms. Replacement of the w-carboxyl group of the most active members of the aminodicarboxylic acid series by sulphonic or sulphinic acid groups leads to the compounds of Table 2, C, which were found to be very active excitants. Indeed, DL-homocysteic acid proved to be 25 times stronger than L-glutamic acid and was one of the most active excitants tested. This correlates with the observation that 3-aminopropanesulphonic acid (Table 1, C) was the most potent depressant. Further correlation is seen in the relative effects of $D$ and $L$ forms of depressant and excitant compounds, $D$ forms being the stronger in every instance (Table 1, E, and Table 2, B, F, H, J).

Less correlation between the depressant and excitant series is observed with $N$-methylation (Table 1, B, and Table 2, F). Whereas mono- $N$-methyl derivatives of $\beta$-alanine and $\gamma$-aminobutyric acid were weaker depressants than the parent compounds, the mono- $N$-methyl derivatives of aspartic and glutamic acids were very much stronger excitants than their unmethylated counterparts. Thus, $N$-methyl-DL-glutamic acid (Table 2, F) and $N$-methyl-DL-aspartic acid (Table 2, F) were found to be respectively 2 and 25 times stronger than the parent compounds. The $\mathrm{D}$ isomer of the latter substance was the strongest excitant found, and was 14 times stronger than the $\mathrm{L}$ isomer and 70 times stronger than the reference compound, L-glutamic acid. The di- and tri- $N$-methyl derivatives of glutamic acid and the 
di- $N$-methyl derivative of aspartic acid were all much less active than the unmethylated, parent compounds, which again parallels the findings within the depressant series.

Another exception to the otherwise close parallelism between the respective structure-activity relationships of the two series is afforded by asparagine (Table $2, \mathrm{H}$ ). This compound, particularly the $\mathrm{D}$ form, displayed marked excitatory activity which is in contrast to the inactivity of $\beta$-alaninamide (Table $1, \mathrm{E}$ ), the analogous compound in Table 1. The $\omega$-amides of L-glutamic acid (L-glutamine, Table 2, H) and $L$-cysteic acid ( $\beta$-sulphamoyl-L-alanine, Table $2, \mathrm{H}$ ) also proved to be excitants, but each was considerably weaker than L-asparagine. In contrast to the $\omega$-amides, the $\alpha$-amides of aspartic and glutamic acids (DL-isoasparagine and L-isoglutamine, respectively, Table 2, I) were inactive.

The remaining sections of Table 2 demonstrate the effects of several other types of structural modification in the excitant series. Isomers of glutamic acid (Table 2. D), arising from changes in the relative positions of the amino-group and the two carboxyl groups, varied in potency, the most active being the branched-chain compound, DL-2-(aminomethyl)succinic acid. Substituents in the carbon chain linking the two carboxyl groups of glutamic acid (Table 2, E) reduced activity, this being very marked with an $\alpha$-methyl group ( $\alpha$-methyl-DL-glutamic acid), but much less so with a $\beta$-hydroxyl group ( $\beta$-hydroxy-DL-glutamic acid). Conversion of the amino-group of L-aspartic acid into the formamidino-group gives the compound $N$ iminomethyl-L-aspartic acid (Table 2, G), which was found to be only slightly less active than the parent compound. Replacement of the amino-groups of aspartic and aminomalonic acids by hydroxyl groups leads respectively to malic and tartronic acids (Table 2, J), each of which exhibited excitatory activity. This was quite marked in D-malic acid but weak in L-malic and tartronic acids.

Other excitatory amino-acids. Preliminary testing of the substances of Table 1 on the fast components of the reflexes recorded from the ventral root in response to dorsal root stimulation demonstrated that several of the substances had excitatory actions. Amongst these were w-amino- and w-guanidino-alkanecarboxylic acids of chain length greater than that at which depressant activity reached a minimum during the ascent of a homologous series (Table 1, A and D). A similar situation occurred in the $\omega$-aminoalkanesulphonic acid series (Table 1,C), but, in these, excitatory activity in the series appeared immediately following the peak of depressant activity. The concentrations of these substances necessary to produce significant increases in the reflex responses were mostly of the order of $10^{-2} \mathrm{M}$ or greater, and such compounds must therefore be classed as only very weak excitants. The excitatory amino-acids of Table 1, like those of Table 2, also caused a negative potential which was recorded by an electrode on the ventral root, but in general the time courses of such actions were somewhat different from those observed with substances of the glutamic acid type. With the relatively low concentrations used, the potentials caused by the latter group developed rapidly after application of the substance, thereafter maintaining a steady level until the substance was washed out. Recovery was also rapid. However, in the long-chain $\omega$-amino, $\omega$-guanidino- and $\alpha$-amino-alkane acids, the negative potentials developed only slowly, and recovery 


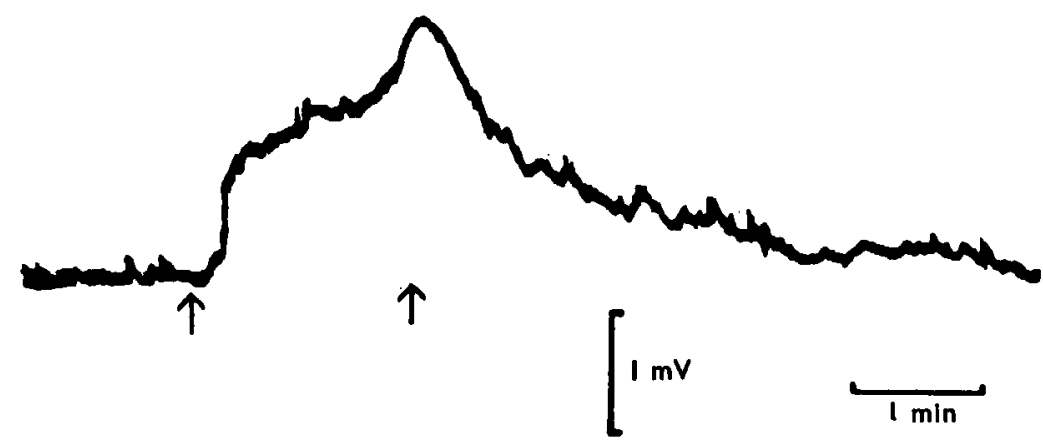

Fig. 6. The potential recorded from the ventral root of a lumbar preparation in response to perfusing the bath with a solution containing $10^{-2} \mathrm{M} 9$-aminononanoic acid. The amino-acid was applied for $90 \mathrm{sec}$ as indicated by the two arrows. Time, min. Voltage calibration, $1 \mathrm{mV}$, negativity upwards.

was similarly protracted. A typical example is provided by 9-aminononanoic acid, illustrated in Fig. 6. Approximately $10 \mathrm{sec}$ after the application of $10^{-2} \mathrm{M}$ 9-aminononanoic acid, a negative potential was recorded from the ventral root, and this increased irregularly until the bath was flushed $90 \mathrm{sec}$ later. Recovery was slow and was still incomplete after $5 \mathrm{~min}$.

Because of these rather different time courses, it was difficult to compare accurately the excitatory amino-acids of this type with those of the glutamate type in regard to their respective potencies. The symbolic indications of their relative potencies given in Table 1 were based upon the approximate concentrations of each which were necessary to produce within two or three minutes the same potential as that produced by $5 \times 10^{-4} \mathrm{M} \mathrm{L-glutamate}$ in $45 \mathrm{sec}$. D-Serine (Table 1, E) acted somewhat more rapidly than did the rest of these substances, and was the most active of the group, being approximately one-half as strong as L-glutamic acid. The $\mathrm{L}$ isomer (Table 1, E) was very much weaker. 9-Aminononanoic acid (Table 1, A) and 4-aminobutanesulphonic acid (Table $1, \mathrm{C}$ ) were the next strongest, these substances both having about one-twentieth of the excitatory activity of L-glutamic acid.

\section{DISCUSSION}

The present studies were undertaken for the purpose of investigating the possible use of the isolated hemisected spinal cord of the toad in a screening programme for substances having an action upon neurones. Such a preparation offers the advantages that it is readily set up, the tissue usually remains responsive to electrical stimulation for many hours, and substances can be applied directly and in controlled concentrations (Bunzl, Burgen, Burns, Pedley \& Terroux, 1954 ; Angelucci, 1956). The technique also avoids some of the uncertainties inherent in many other test situations, since effects observed cannot rise indirectly from peripheral receptors or follow alterations in blood flow (Curtis, Phillis \& Watkins, 1961). Furthermore, the access of the applied substances to the centrally located neurones cannot be hindered by the blood-brain barrier. However, any observed action involves possible effects upon many cells, some types of which may react in a qualitatively or quantitatively 
different manner from other types. This feature precludes direct knowledge of the precise site and mode of action of a particular test substance, but may occasionally be an advantage by making apparent actions of substances which may not be detected by more restrictive methods. For the purposes of the present study, two series of amino-acids and substances closely related to amino-acids were selected so as to cover the most important findings of several similar investigations undertaken recently on a variety of excitable tissues (Purpura et al., 1959 ; Edwards \& Kuffler, 1959 ; Robbins, 1959 ; Van Harreveld, 1959 ; Curtis \& Watkins, 1960). $\gamma$-Aminobutyric acid and L-glutamic acid were chosen as standard depressant and excitant substances respectively, and their actions upon the responses of the isolated hemisected toad cord were briefly investigated prior to their use as reference compounds for the estimation of the relative potencies of the other substances in the two series.

$\gamma$-Aminobutyric acid was selected as the standard depressant substance for the reasons that on all preparations it appears to be amongst the most potent of the $\omega$-amino-acids and its action has been the most widely studied. Thus, $\gamma$-aminobutyric acid depresses the responses of the amphibian spinal cord in situ (Sigg \& Grundfest, 1958 ; Tsujioka \& Fukuya, 1958), the stretch receptor of the crayfish (Bazemore, Elliott \& Florey, 1956 ; Edwards \& Kuffler, 1957 ; Hagiwara, Kusano \& Saito, 1960), the perfused lobster heart (Enger \& Burgen, 1957), the lobster cardiac ganglion (Maynard, 1958), mammalian ileum (Hobbiger, 1958), mammalian cerebral cortex (Hayashi \& Nagai, 1956 ; Purpura, Girado \& Grundfest, 1957 ; Iwama \& Jasper, 1957 ; Jasper, Gonzales \& Elliott, 1958 ; Marrazzi, Hart \& Rodriguez, 1958 ; Takahashi, Nagashima, Koshino \& Takahashi, 1959), and mammalian spinal neurones (Curtis, Phillis \& Watkins, 1959). The observed depressant action of $\gamma$-aminobutyric acid on the reflex responses of the isolated hemisected spinal cord of the toad is in accordance with the observations of Sigg \& Grundfest (1958) and Tsujioka \& Fukuya (1958) on responses recorded in situ from the spinal cord of the bull frog.

L-Glutamic acid was selected as the standard excitatory substance for similar reasons to those relating to the choice of $\gamma$-aminobutyric acid as the standard depressant, and also because of its close structural relationship with the latter. Glutamic acid has been shown to have an excitant action on crustacean muscle (Robbins, 1959 ; Van Harreveld, 1959 ; Van Harreveld \& Mendelson, 1959) and mammalian spinal neurones (Curtis, Phillis \& Watkins, 1960). The action of this substance in eliciting spreading depression of mammalian cortical cells (Van Harreveld, 1959 ; Purpura et al., 1959) also probably results from a preliminary excitatory action, followed, in this case, by excessive depolarization which inactivates the cells (Curtis \& Watkins, 1960). In the case of the isolated toad cord, L-glutamic acid was found to cause a marked enhancement of the fast components of the reflex evoked by dorsal root stimulation. With high glutamic acid concentrations, this increased excitation reached a maximum and then rapidly subsided, presumably because excessive depolarization led to inactivation of the spike mechanism of many of the cells (Curtis, Phillis \& Watkins, 1960). During the initial period of enhanced excitability, spike responses were evoked independently of dorsal root stimulation. The depolarizations of motoneurones responsible for these effects were propagated 
electrotonically along axons of the ventral root where they were recorded as negative potentials in relation to an indifferent electrode situated in the bath. The extent of the depolarization was related to the concentration of the amino-acid. It is significant that the potentials recorded in cases of high glutamic acid concentration showed a sharp increase at the point where high-frequency spike activity ceased, this fact supporting the postulate that such cessation is associated with excessive depolarization of previously discharging cells. Following the action of high concentrations of glutamic acid, spike activity, which had ceased during the continued presence of the amino-acid, transiently recommenced during the period following washing. This effect was probably due to partial reactivation of the spike generating mechanism as the glutamate-induced depolarization subsided towards the threshold for spike initiation.

In the investigation of the relative activities of substances related to $\gamma$-aminobutyric acid and glutamic acid the most interesting result was the greater potency of the $D$ compared with the $L$ forms of active substances in both series. This was found to be true of every substance where both isomers were available. The stereo-difference was more marked, as would be expected, the larger the difference in the sizes of the groups attached to the asymmetric carbon atom. Thus, there was a fourteenfold difference between the $\mathrm{D}$ and $\mathrm{L}$ forms of $N$-methylaspartic acid, but only a very slight difference in the two forms of aspartic acid. $N$-Methyl-D-aspartic acid was indeed a remarkably potent excitant, being 70 times more effective than L-glutamic acid on a concentration basis. This correlates to some extent with the fact that the DL form of the same compound had a very prolonged action when iontophoretically applied to interneurones in the cat's spinal cord (Curtis \& Watkins, 1960), but in this case the compound was rated somewhat weaker than L-glutamic acid because the latter required smaller iontophoretic currents to produce similar frequencies of interneuronal discharge. Similar, though less marked, stereo-differences were evident in the depressant actions of $D$ - and $L-\alpha$-alanine and in the excitant actions of D- and L-glutamic acid, D- and L-asparagine, D- and L-malic acid, and D- and Lserine. That a similar stereo-dependence may occur in the case of amino-acid actions on mammalian cortical cells is suggested by the greater apparent potency of $D$ - than L-glutamic acid in producing spreading depression, although in these acids enzymic destruction of the $L$ form has been proposed as a possible explanation (Van Harreveld, 1959). Similar considerations may also apply in the case of the toad cord results with those amino-acids whose $L$ forms are probably normal constituents of the tissue, but would seem less likely to explain the differential potency of $\mathrm{D}$ and $\mathrm{L}$ forms of $N$-methylaspartic acid. This is a synthetic amino-acid which has not been reported to occur in nature, and neither of the forms would be expected to be metabolized at a rate sufficiently rapid to influence the results.

Another interesting result was the extremely strong actions of the sulphonic acids, 3-aminopropanesulphonic acid and DL-homocysteic acid. The former compound was found to be the most powerful depressant tested, and the latter, together with $N$-methyl-DL-aspartic acid, the strongest of all racemic excitatory compounds. The structural requirements for high activity in the aminosulphonic acid series, at least in the case of the depressants, appear to be more rigid than those for the amino- 
carboxylic acids. A primary amino-group and a chain length of two or three carbon atoms between the acidic and basic terminal groups were much more essential for high depressant activity in the sulphonic acid than in the carboxylic acid series.

It is noteworthy that 3-aminopropanesulphonic acid and homocysteic acid bear the same structural relationship to each other as do $\gamma$-aminobutyric acid and glutamic acid, which provides another example of the general rule (Curtis \& Watkins, 1960) that, if an $\omega$-amino-acid is a strong depressant, the corresponding acidic amino-acid, containing an additional carboxyl group alpha to the amino-group, will be a strong excitant. The converse of this rule, though found to be equally true in the case of iontophoretic experiments on interneurones of the cat's spinal cord, is not valid in some instances in the case of the isolated toad cord. Thus, the strong excitant asparagine, on removal of the $\alpha$-carboxyl group, becomes not a depressant but an inactive compound ( $\beta$-alaninamide). The weak excitant, $L$-glutamine, and the inactive decarboxylation product, $\gamma$-aminobutyramide, provide an additional, if less significant, example. The corresponding amide of L-cysteic acid, $\beta$-sulphamoyl-Lalanine, also had weak excitatory activity, but the decarboxylated analogue was not available for testing.

The structure-activity relationships apparent from the results shown in Tables 1 and 2 are in general agreement with those of similar studies on the actions of the same and related substances on other tissues (Edwards \& Kuffler, 1959 ; Purpura et al., 1959 ; Robbins, 1959 ; Van Harreveld, 1959 ; Curtis \& Watkins, 1960). Where tissues involving a multiplicity of cells were used (Purpura et al., 1959; Van Harreveld, 1959), the correlation is extremely close. However, when comparison is made of the toad cord results with those of the same substances applied iontophoretically to single cells of the cat's spinal cord (Curtis \& Watkins, 1960), certain discrepancies are apparent. These mainly involve the moderate to strong actions observed on the toad cord by D- and L-asparagine, D-serine and glycocyamine. These substances were inactive when applied iontophoretically around interneurones of the cat's spinal cord, although adequate concentrations should have been obtained to affect the excitability of these cells if the substances were indeed active thereon. The lack of correlation between these two sets of results may possibly be extended to include the long-chain $\omega$-amino- and $\omega$-guanidino-alkane acids, as well as several other substances which were found to be weak excitants on the frog cord. These substances also were without effect on single cells of the cat cord, but the concentrations attainable by the iontophoretic technique (Curtis, Perrin \& Watkins, 1960) may not have been adequate to demonstrate weak actions.

It must be re-emphasized that the gross responses of a tissue composed of a mass of cells, involving almost certainly many different functional types, does not allow conclusions to be drawn regarding the sites or mechanism of action of a particular substance. Thus, the explanation of the differences observed between the gross actions of compounds on such tissues and those on single cells in other tissues may lie in a differential responsiveness of individual cells to the substances under test ; or in a possible alteration of extracellular levels of endogenous active substances because of the inhibition of enzyme systems by the test substances; or, again, in enzymic conversion of the test substances, themselves perhaps inactive, into active 
substances (Curtis \& Watkins, 1960 ; Curtis, 1961). Indeed, a possible indication of different sites and/or modes of action of the glutamic acid and long-chain $\omega$-aminoalkane (or $\omega$-guanidinoalkane) acid types of excitant is the different time courses of the respective actions of these groups. The disparity in chemical structure between the two types may also be taken to indicate that different receptors and modes of actions are involved. However, this is less likely to be the case in regard to the actions of aspartic acid, asparagine, malic acid and serine, which are chemically much more closely related to one another. Furthermore, the time courses of action of these substances are not dissimilar, and the relative rapidity of these actions suggests that each is acting directly upon cell membranes. Were this to be the case, and a common site of action to be involved, certain implications with regard to the structural features of this common receptor site merit brief discussion. At physiological $p \mathrm{H}$, asparagine, malic acid and serine do not possess the two anionic groups and one cationic group considered to be essential for combination with the amino-acid receptor of mammalian spinal neurones (Curtis \& Watkins, 1960). Each of these substances does possess, however, in common with aspartic acid, three groups capable of forming co-ordinate bonds with metals. It is possible to envisage a type of receptor which could be involved in complex formation with each of these four substances, but which does not differ significantly in its main features from that proposed for mammalian spinal neurones. Thus, the receptor may involve one or two metal atoms, these being complexed with the membrane in a region to which access is limited by the nature and spatial arrangement of surrounding membrane atoms. If only one metal atom were involved, excitation could be envisaged to occur when an anionic group of the amino-acid or hydroxy acid became bound to a non-metallo-cationic site on the receptor in such a manner as to allow the two other functional groups to co-ordinate with the near-by metal atom. If two metal atoms were involved, co-ordinate bonds could form between each of the three functional groups of the substances and one or other of the metal atoms. Membrane elements in the immediate environment of the metal atoms might vary from cell to cell and tissue to tissue, and this could provide an explanation for the somewhat different structure -activity relationships which have been observed in the various investigations. These differences could thus arise because of varying degrees of interference by projecting atoms or groups of the membrane to combination of the test substance with the binding sites of the receptor. The well-known importance of calcium and magnesium in neural function (Shanes, 1958) and the occurrence of copper proteins in brain (Porter \& Folch, 1957 ; Porter \& Ainsworth, 1959) suggest possible metals which may well form complexes with neuronal membranes and which, under favourable conditions, could also form co-ordinate bonds with amino-acids and hydroxy acids.

\section{REFERENCES}

ANGEluCC1, L. (1956). Experiments with perfused frog's spinal cord. Brit. J. Pharmacol., 11,

ARAKI, T. (1960). Effects of electrotonus on the electrical activities of spinal motoneurones of the toad. Jap. J. Physiol., 10, 518-532.

Araki, T., Otani, T. \& Furukawa, T. (1953). The electrical activities of single motoneurons in toad's spinal cord, recorded with intracellular electrodes. Jap. J. Physiol., 3, 254-267.

Bazemore, A., Elliotr, K. A. C. \& Florey, E. (1956). Factor I and $\gamma$-aminobutyric acid. Nature (Lond.), 178, 1052-1053. 
Brockman, J. A. \& Burson, S. L. (1957). Multiple nature of inhibitory factor (Factor I) from brain. Proc. Soc. exp. Biol., 94, 450-452.

Brookhart, J. M., MachNe, X. \& Fadiga, E. (1959). Patterns of motor neuron discharge in the frog. Arch. ital. biol., 97, 53-67.

Bunzl, A., Burgen, A. S. V., Burns, D., Pedley, N. \& Terroux, K. G. (1954). Methods for studying the reflex activity of the frog's spinal cord. Brit. J. Pharmacol., 9, 229-235.

CURTIS, D. R. (1961). The effects of drugs and amino acids upon neurons. In The Regional Chemistry, Physiology and Pharmacology of the Nervous System. Oxford: Pergamon Press.

Curtis, D. R. \& Watkns, J. C. (1960). The excitation and depression of spinal neurones by structurally related amino acids. J. Neurochem., 6, 117-141.

Curtis, D. R., Perrin, D. D. \& Watkins, J. C. (1960), The excitation of spinal neurones by the ionophoretic application of agents which chelate calcium. J. Neurochem., 6, 1-20.

Curtis, D. R., Phillis, J. W. \& Watkins, J. C. (1959). The depression of spinal neurones by $\gamma$-amino-n-butyric acid and $\beta$-alanine. J. Physiol., 146, 185-203.

Curtis, D. R., Phillis, J. W. \& Watkins, J. C. (1960). The chemical excitation of spinal neurones by certain acidic amino acids. J. Physiol., 150, 656-682.

Curtis, D. R., Phillis, J. W. \& Watkins, J. C. (1961). Cholinergic and non-cholinergic transmission in the spinal cord. $J$. Physiol. In the press.

ECCLES, J. C. (1946). Synaptic potentials of motoneurones. J. Neurophysiol., 9, 87-120.

ECCLES, J. C. (1947). Acetylcholine and synaptic transmission in the spinal cord. J. Neurophysiol., 10, 197-204.

EDWARDS, C. \& KUfFLER, S. W. (1957). Inhibitory mechanisms of gamma aminobutyric acid on an isolated nerve cell. Fed. Proc., 16, 34.

EDWARDS, C. \& KUfFLER, S. W. (1959). The blocking effect of $\gamma$-aminobutyric acid (GABA) and the action of related compounds on single nerve cells. J. Neurochem., 4, 19-30.

ENGer, P. E. S. \& BURgen, A. S. V. (1957). The effects of some amino acids on the perfused lobster heart. Biol. Bull., 113, 345-346.

Hagtwara, S., Kusano, K. \& Satto, S. (1960). Membrane changes in cray fish stretch receptor neuron during synaptic inhibition and under action of gamma-aminobutyric acid. $J$. Neurophysiol., 23, 505-515.

HaYashi, T. \& NaGaI, K. (1956). Action of w-amino acids on the motor cortex of higher animals, especially $\gamma$-amino- $\beta$-oxybutyric acid as the real inhibitory principle in brain. $A b s t r . X X$. int. physiol, Congr., 410.

Hobbiger, F. (1958). Effects of $\gamma$-aminobutyric acid on the isolated mammalian ileum. J. Physiol., $142,147-164$.

INouYe, A., FukuYa, M., TsuchiYA, K. \& TsujiokA, T. (1960). Studies on the effects of $\gamma$-aminobutyric acid on the isolated guinea-pig ileum. Jap. J. Physiol., 10, 167-182.

IWAMA, K. \& JASPER, H. H. (1957). The action of gamma aminobutyric acid upon cortical electrical activity in the cat. J. Physiol., 138, 365-380.

JASPER, H., Gonzalez, S. \& ElliotT, K. A. C. (1958). Action of $\gamma$-aminobutyric acid (GABA) and strychnine upon evoked electrical responses of cerebral cortex. Fed. Proc., 17, 79.

MAChNe, X., Fadiga, E. \& Brookhart, J. M. (1959). Antidromic and synaptic activation of frog motor neurones. $J$. Neurophysiol., 22, 483-503.

Marrazzi, A. S., Hart, E. R. \& Rodriguez, J. M. (1958). Action of blood-borne gamma-aminobutyric acid on central synapses. Science, 127, 284-285.

MaYNard, D. M. (1958). Action of drugs on lobster cardiac ganglion. Fed. Proc., $17,106$.

PORTER, H. \& AINSWORTH, S. (1959). The isolation of the copper-containing protein cerebrocuprein I from normal human brain. J. Neurochem., 5, 91-98.

PoRter, H. \& Folch, J. (1957). Cerebrocuprein I. A copper-containing protein isolated from brain. J. Neurochem., 1, 260-271.

Purpura, D. P., Girado, M. \& Grundfest, H. (1957). Selective blockade of excitatory synapses in the cat brain by $\gamma$-aminobutyric acid. Science, 125, 1200-1202.

Purpura, D. P., Girado, M., Smith, T. G., Callan, D. A. \& Grundfest, H. (1959). Structure activity determinants of pharmacological effects of amino acids and related compounds on central synapses. J. Neurochem., 3, 238-268.

Robbins, J. (1959). The excitation and inhibition of crustacean muscle by amino acids. J. Physiol., 148, 39-50. 
Shanes, A. M. (1958). Electrochemical aspects of physiological and pharmacological action in excitable cells. Pharmacol. Rev., 10, 59-274.

SigG, E. \& GrUNDFest, H. (1958). Pharmacological specification of electrogenic membranes in bull frog C.N.S. Fed. Proc., 17, 149.

Takahashi, H., Nagashima, A., Koshino, C. \& Takahashi, H. (1959). Effects of $\gamma$-aminobutyric acid (GABA), $\gamma$-aminobutyryl choline (GABA-Ch) and their related substances on the cortical activity. Jap. J. Physiol., 9, 257-265.

Tsujoka, T. \& Fukuya, M. (1958). Cited by Inouye, A., Fukuya, M., Tsuchiya, K. \& Tsujioka, T. (1960). Studies on the effects of $\gamma$-aminobutyric acid on the isolated guinea-pig ileum. Jap. J. Physiol., 10, 167-182.

Van Harreveld, A. (1959). Compounds in brain extracts causing spreading depression of cerebral cortical activity and contraction of crustacean muscle. J. Neurochem., 3, 300-315.

VAN HARreveld, A. \& Mendelson, M. (1959). Glutamate-induced contractions in crustacean muscle. J. cell. comp. Physiol., 54, 85-94. 